\title{
PEMANFAATAN APLIKASI SMARTPHONE UNTUK MENGUKUR KEMANTAPAN PERMUKAAN JALAN BERDASARKAN INTERNATIONAL ROUGHNESS INDEX
}

\author{
Arief Setiawan \\ Jurusan Teknik Sipil \\ Fakultas Teknik \\ Universitas Tadulako \\ rief_mt@yahoo.co.id
}

\author{
Novita Pradani \\ Jurusan Teknik Sipil \\ Fakultas Teknik \\ Universitas Tadulako \\ novpradani@gmail.com
}

\author{
Ferra Claudia Masoso \\ Jurusan Teknik Sipil \\ Fakultas Teknik \\ Universitas Tadulako \\ ferraclaudia10@gmail.com
}

\begin{abstract}
An assessment of road surface conditions is needed to determine an appropriate road evaluation program. One of the parameters used is the International Roughness Index or IRI. Currently, technological developments encourage the use of smartphone applications as a tool to determine the value of IRI. Comparisons between IRIs obtained using tools, such as roughometers, and IRIs obtained from software applications have not been made. The purpose of this study was to analyze the relationship between the results of the measurement of the roughometer and the results of the Android application Roadbump Pro. This research was carried out on the Sam Ratulangi Road in Palu City, with a segment length of 600 meters and analyzed per 100 meters. The results of this study indicate that smartphone applications provide good IRI measurement results, so they can be used in road stability assessments. In addition, the type of survey vehicle did not have a significant effect on IRI measurements.
\end{abstract}

Keywords: smartphone, International Roughness Index, roughometer, Roadbump, road stability

\begin{abstract}
Abstrak
Penilaian kondisi permukaan jalan diperlukan untuk menentukan program evaluasi jalan yang tepat. Salah satu parameter yang digunakan adalah International Roughness Index atau IRI. Saat ini, perkembangan teknologi mendorong penggunaan aplikasi smartphone sebagai alat bantu untuk menentukan nilai IRI. Perbandingan antara IRI yang diperoleh dengan menggunakan alat bantu, seperti roughometer, dan IRI yang diperoleh dari aplikasi perangkat lunak belum dilakukan. Tujuan penelitian ini adalah menganalisis hubungan antara hasil pengukuran alat roughometer dan hasil aplikasi android Roadbump Pro. Penelitian ini dilakukan di ruas Jalan Sam Ratulangi di Kota Palu, dengan panjang segmen 600 meter dan dianalisis per 100 meter. Hasil penelitian ini menunjukkan bahwa aplikasi smartphone memberikan hasil pengukuran IRI yang baik, sehingga dapat digunakan dalam penilaian kemantapan jalan. Selain itu, jenis kendaraan survei tidak memberikan pengaruh yang signifikan terhadap pengukuran IRI.
\end{abstract}

Kata-kata kunci: smartphone, International Roughness Index, roughometer, Roadbump, kemantapan jalan

\section{PENDAHULUAN}

Penilaian kondisi jalan, baik struktural maupun non-struktural, perlu dilakukan secara periodik agar menjadi acuan dalam menentukan jenis program evaluasi jalan yang harus dilakukan. Program evaluasi jalan meliputi program peningkatan, pemeliharaan berkala, dan pemeliharaan rutin. Pemilihan program pemeliharaan jalan dilakukan dengan melakukan penilaian terhadap kondisi permukaan jalan. Menurut Tho'atin et al. (2016), 
metode yang dapat digunakan untuk menilai kondisi permukaan jalan adalah metode International Roughness Index (IRI) dan metode visual, yaitu metode Surface Distress Index (SDI) dan Pavement Condition Index.

Paterson (1986) melakukan penelitian hubungan antara IRI dengan parameter kerataan jalan dan kualitas berkendara, yaitu quarter-car index, bump integrator trailer, coefficient of planarity, short wavelength energy, coefficient of Analyseur de Profil en Long (APL) profilometer, serviceability index, dan Inches/mile equivalent of IRI. Hasil penelitian ini mendorong penerapan IRI secara luas sebagai referensi dan standar kalibrasi di seluruh dunia untuk pengukuran kerataan jalan. IRI menjadi sebutan umum dan paralel dengan indeks kerataan lokal yang berkaitan dengan kerataan permukaan jalan.

Secara matematis, IRI merupakan rangkuman beda tinggi permukaan longitudinal jalan yang dilalui roda, mewakili getaran akibat kekasaran permukaan jalan yang diinduksi oleh mobil penumpang tipikal. IRI dihitung dari data ketinggian permukaan akibat kekasaran permukaan jalan yang dikumpulkan dari survei topografi atau menggunakan profilometer secara mekanik. IRI ini dinyatakan dalam satuan $\mathrm{m} / \mathrm{km}$ atau inci/mil (Gillespie et al., 1980).

Tantangan untuk menggunakan alat bantu dalam mengukur IRI secara efektif dan efisien dapat dijawab dengan teknologi smartphone dan aplikasinya. Perangkat ini semakin populer saat ini dan dengan daya pemrosesan yang tinggi, serta kemampuan untuk mentransfer data melalui jaringan nirkabel. Aplikasi berbasis smartphone telah muncul dalam beberapa tahun terakhir untuk menyelesaikan masalah lama dengan pendekatan baru yang lebih efisien dan murah.

Perbandingan antara IRI yang menggunakan alat bantu, seperti roughometer, dan IRI yang menggunakan aplikasi software IRI belum dilakukan. Karena itu, penelitian ini menjadi penting untuk memberikan informasi tambahan mengenai hubungan antara pengukuran oleh aplikasi dan pengukuran langsung dengan alat. Pada studi dilakukan analisis hubungan antara pengukuran alat roughometer dan aplikasi android Roadbump Pro. Roadbump Pro merupakan suatu aplikasi android yang mudah diperoleh di pasaran. Penelitian ini juga diharapkan memberi informasi tentang pemanfaatan aplikasi dalam menilai kemantapan jalan.

\section{Lokasi Penelitian}

Penelitian ini dilakukan di ruas Jalan Sam Ratulangi di Kota Palu, Indonesia. Status Jalan Sam Ratulangi adalah jalan nasional dengan rentang kecepatan rencana $50 \mathrm{~km} / \mathrm{jam}$ sampai 80 km/jam (BSN, 2004). Tipe Jalan Sam Ratulangi adalah 4/2 UD atau 4 lajur 2 arah tidak terbagi, dan panjang ruas jalan yang diamati adalah $600 \mathrm{~m}$, yaitu antara persimpangan jalan Jalan Raden Saleh-Jalan S. Parman dan Jalan Sam Ratulangi dengan Jembatan Talise. Gambar 1 dan Gambar 2 menunjukkan lokasi penelitian dan segmen ruas jalan untuk pengukuran IRI. 


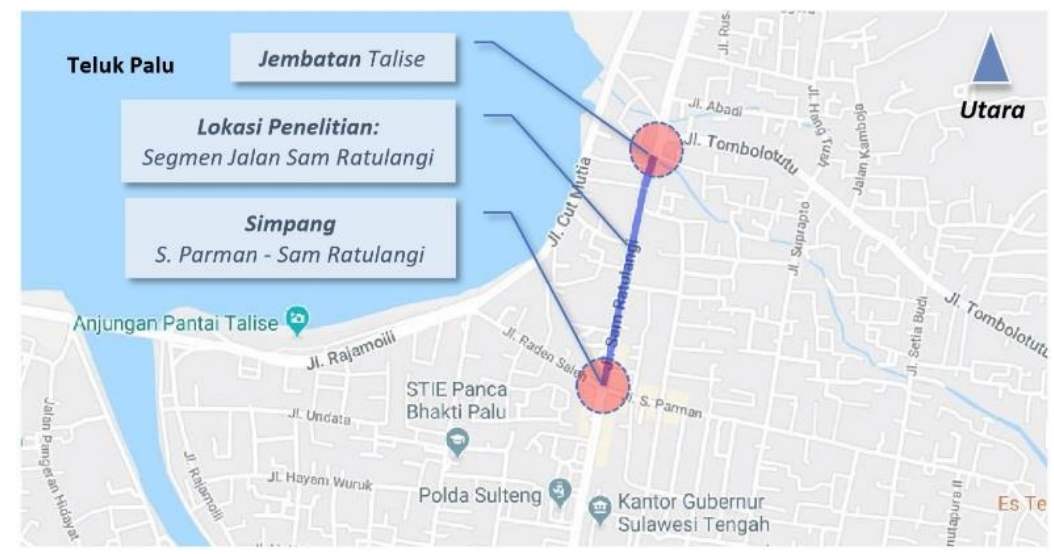

Gambar 1 Segmen Ruas Jalan Sam Ratulangi Kota Palu sebagai Obyek Pengukuran IRI

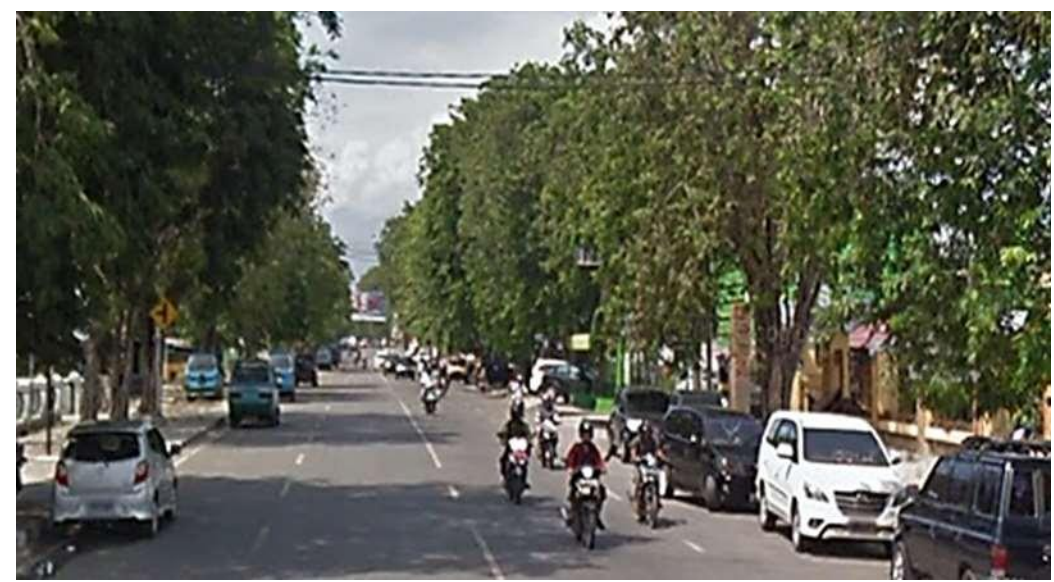

Gambar 2 Situasi Jalan Sam Ratulangi Kota Palu

\section{Aplikasi Road Bump Pro}

Roadbump Pro adalah aplikasi smartphone android yang dikembangkan oleh David Grimmer untuk mengukur kerataan permukaan jalan dan menghasilkan nilai IRI. Grimmer Software (2019) menyatakan bahwa aplikasi ini telah digunakan lebih dari 25 negara. Hasil pengukuran Roadbump adalah estimasi IRI dan grafik akselerometer yang menunjukkan tonjolan, dips dan gelombang pada semua jenis permukaan jalan, seperti jalan beraspal, jalan beton, dan jalan kerikil (Grimmer Software, 2019).

Penggunaan Roadbump Pro dilakukan dengan urutan sebagai berikut:

1) Smartphone yang sudah memiliki aplikasi Roadbump Pro diletakkan di dashboard mobil dengan alas antislip atau dipasang di kaca depan bagian dalam mobil;

2) Aplikasi disetel berdasarkan pilihan: (a) unit of measure: metric; (b) minimum speed: 20 $\mathrm{km} / \mathrm{jam}$, (c) vehicle/device factor: 0,75 untuk pickups; 1,0 untuk SUVs; dan 1,2 untuk sedan; dan (d) accelerometer rate: fastest-maximize accuracy; serta

3) Tombol start ditekan pada titik awal jalan yang akan diukur, mobil berjalan dengan kecepatan lebih tinggi dari $20 \mathrm{~km} / \mathrm{jam}$ dan bervariasi normal kemudian tombol stop ditekan ketika sudah mencapai titik akhir ruas jalan yang ditinjau. 
Pengukuran di lapangan dan pengolahan data dilakukan dengan urutan sebagai berikut.

1) Pengukuran IRI dilakukan pada tiap lajur Jalan Sam Ratulangi, dengan skema pengambilan data pada ruas jalan tersebut dapat dilihat pada Gambar 3;

2) Pengambilan data dilakukan sebanyak 3 kali dan dikontrol konsistensinya;

3) Pengamatan data dilakukan per 100 meter untuk mendapatkan informasi yang relatif detail;

4) Pengereman mendadak selama survei dihindari, sehingga waktu survei dipilih pada saat tidak jam puncak; dan

5) Penggujian menggunakan 3 jenis mobil sebagai kendaraan survei, yaitu: (a) multi purpose vehicle (MPV), (b) sedan, dan (c) pickup, dengan tujuan untuk mengetahui pengaruh jenis kendaraan terhadap hasil survei IRI.

Karakteristik setiap kendaraan survei adalah:

a) Jenis MPV yang digunakan adalah mobil Avanza, dengan umur kendaraan sekitar 5 tahun, dan faktor kendaraan yang dipilih untuk jenis mobil MPV adalah 1,1;

b) Jenis sedan yang digunakan adalah mobil Toyota Corolla, dengan umur kendaraan sekitar 8 tahun, dan faktor kendaraan jenis mobil sedan adalah 1,2; dan

c) Jenis pickup yang digunakan adalah mobil Mitsubishi Strada, yang dapat menggunakan sistem penggerak roda depan belakang atau four-wheel drive (4WD), tetapi pada survei ini hanya dilakukan dengan menggunakan 2WD, dengan umur kendaraan sekitar 9 tahun, dan faktor kendaraan pickup adalah 0,75 .

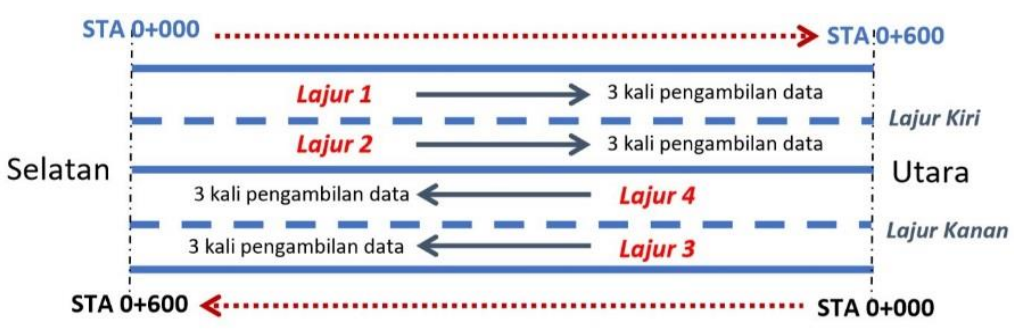

Gambar 3 Skema Arah Pergerakan Kendaraan Survei dan Jumlah Pengambilan Data

\section{Alat Roughometer III}

Roughometer III adalah perangkat pengukur kekasaran permukaan jalan. AARB (2016) menyatakan bahwa Roughometer III memiliki kelebihan dalam menghilangkan ketidakpastian yang terkait dengan kendaraan, seperti suspensi kendaraan atau berat penumpang, dengan langsung mengukur gerakan gandar dengan accelerometer yang presisi. Karena itu Roughometer III tidak perlu dikalibrasi secara eksperimental untuk menghasilkan nilai IRI.

Seperangkat Roughometer III digunakan oleh Balai Pelaksanaan Jalan Nasional XIV Palu (2018) untuk menentukan nilai IRI di ruas Jalan Sam Ratulangi Palu. Hasil pengukuran IRI pada segmen Jalan Sam Ratulangi, sepanjang 600 meter dengan interval per 100 meter, disajikan pada Tabel 1 . 
Tabel 1 Hasil Pengukuran IRI dengan Menggunakan Roughometer III

\begin{tabular}{|c|c|c|c|c|c|}
\hline \multirow[b]{2}{*}{ STA } & \multirow[b]{2}{*}{ Interval } & \multicolumn{2}{|c|}{ Ke Arah Utara } & \multicolumn{2}{|c|}{ Ke Arah Selatan } \\
\hline & & $\begin{array}{c}\text { IRI } \\
(\mathrm{m} / \mathrm{km})\end{array}$ & $\begin{array}{c}\text { Kecepatan } \\
(\mathrm{km} / \mathrm{jam})\end{array}$ & $\begin{array}{c}\text { IRI } \\
(\mathrm{m} / \mathrm{km})\end{array}$ & $\begin{array}{c}\text { Kecepatan } \\
\text { (km/jam) }\end{array}$ \\
\hline $000+100$ & 100 & 5,2 & 37 & 6,4 & 36 \\
\hline $000+200$ & 100 & 6,1 & 37 & 5,5 & 38 \\
\hline $000+300$ & 100 & 4,5 & 42 & 4,5 & 30 \\
\hline $000+400$ & 100 & 3,5 & 45 & 4,5 & 32 \\
\hline $000+500$ & 100 & 3,7 & 43 & 6,2 & 33 \\
\hline $000+600$ & 100 & 3,5 & 43 & 3,7 & 28 \\
\hline & Rata-rata & 4,4 & 41,2 & 5,1 & 32,8 \\
\hline
\end{tabular}

Sumber: BPJN XIV Palu (2018).

\section{Ukuran Kemantapan Jalan}

Data IRI yang telah diperoleh dievaluasi dengan menggunakan standar yang dikeluarkan oleh Peraturan Menteri Pekerjaan Umum (2011), seperti terlihat pada Tabel 2. Klasifikasi kondisi jalan ditentukan berdasarkan LHRT yang dibagi dalam 8 tipe nilai LHRT, tetapi pada Tabel 2 hanya ditampilkan LHRT lebih besar dari $12.000 \mathrm{smp} / \mathrm{hari}$, karena data hasil survei di Jalan Sam Ratulangi pada tahun 2019 menunjukkan jumlah kendaraan mobil penumpang dan kendaraan berat adalah 14.344,9 smp/hari.

Tabel 2 Penentuan Kondisi Ruas Jalan Berdasarkan Nilai IRI dan Volume Lalu lintas

\begin{tabular}{ccc}
\hline $\begin{array}{c}\text { IRI Rata-Rata } \\
(\mathrm{m} / \mathrm{Km})\end{array}$ & Kondisi Jalan & $\begin{array}{c}\text { Tingkat } \\
\text { Kemantapan Jalan }\end{array}$ \\
\cline { 2 - 2 } $0-3,5$ & LHRT $(>12.000 \mathrm{smp} /$ hari $)$ & Jalan mantap \\
$3,5-6$ & Baik & Sedang \\
\hline $6-8$ & Rusak Ringan & Jalan tidak mantap \\
$>8$ & Rusak Berat &
\end{tabular}

Catatan: LHRT = Lalu Lintas Harian Rata-Rata Tahunan.

Sumber: (Kementerian PU, 2011).

\section{HASIL DAN PEMBAHASAN}

\section{Hasil Pengukuran Data IRI Menggunakan Roadbump Pro}

Data hasil pengukuran IRI disajikan pada Tabel 3, untuk pengukuran dengan kendaraan survei jenis MPV, untuk masing-masing arah. Demikian juga pada Tabel 4, untuk kendaraan sedan, serta pada Tabel 5, untuk kendaraan survei jenis pickup. Hasil perhitungan deviasi standar menunjukkan bahwa deviasi standar IRI terendah ditunjukkan oleh kendaraan jenis MPV, yaitu sebesar $0,415 \mathrm{~m} / \mathrm{km}$, sedangkan yang tertinggi diberikan oleh kendaraan jenis pickup, yaitu $1,153 \mathrm{~m} / \mathrm{km}$. Deviasi standar yang tinggi pada kendaraan pickup pada penelitian ini diduga karena umur mobil tersebut paling tua dibandingkan 2 jenis mobil yang lain, yaitu sekitar 9 tahun, sehingga suspensi kendaraan kurang elastis.

Kecepatan rata-rata ketiga kendaraan survei adalah $28,6 \mathrm{~km} / \mathrm{jam}$ dengan deviasi standar 3,4 km/jam. Kecepatan kendaraan yang digunakan pada survei ini dengan tingkat kepercayaan 95\% memiliki rentang kecepatan 25,05 km/jam sampai dengan 32,21 km/jam. Kecepatan kendaraan ini dengan perubahan kecepatan sekitar $7 \mathrm{~km} / \mathrm{jam}$ dapat dijadikan referensi dalam pengambilan data IRI menggunakan aplikasi Roadbump Pro. 
Tabel 3 Data IRI Hasil Roadbump Pro dengan Kendaraan Survei Jenis MPV

\begin{tabular}{|c|c|c|c|c|c|c|c|c|c|}
\hline \multirow[b]{2}{*}{ STA } & \multirow[b]{2}{*}{ Interval } & \multicolumn{3}{|c|}{ IRI (m/km) } & \multirow{2}{*}{$\begin{array}{c}\text { Kecepatan } \\
\text { Rata-rata } \\
(\mathrm{km} / \mathrm{jam})\end{array}$} & \multicolumn{3}{|c|}{ IRI (m/km) } & \multirow{2}{*}{$\begin{array}{r}\text { Kecepatan } \\
\text { Rata-rata } \\
\text { (km/jam) }\end{array}$} \\
\hline & & $\begin{array}{c}\text { Rata-rata } \\
\text { Lajur } 1\end{array}$ & $\begin{array}{c}\text { Rata-rata } \\
\text { Lajur } 2 \\
\end{array}$ & $\begin{array}{c}\text { Rata- } \\
\text { rata }\end{array}$ & & $\begin{array}{c}\text { Rata-rata } \\
\text { Lajur } 3 \\
\end{array}$ & $\begin{array}{c}\text { Rata-rata } \\
\text { Lajur } 4\end{array}$ & $\begin{array}{c}\text { Rata- } \\
\text { rata }\end{array}$ & \\
\hline $000+100$ & 100 & 5,41 & 4,56 & 5,5 & 29,7 & 6,84 & 6,39 & 6,6 & 22,1 \\
\hline $000+200$ & 100 & 5,80 & 6,62 & 6,2 & 29,3 & 5,91 & 5,76 & 5,8 & 22,7 \\
\hline $000+300$ & 100 & 4,97 & 4,57 & 4,8 & 29,3 & 4,74 & 4,58 & 4,7 & 23,9 \\
\hline $000+400$ & 100 & 4,03 & 3,30 & 3,7 & 29,3 & 4,61 & 4,63 & 4,6 & 24,3 \\
\hline $000+500$ & 100 & 4,03 & 4,00 & 4,0 & 30,6 & 6,35 & 6,21 & 6,3 & 25,5 \\
\hline $000+600$ & 100 & 4,00 & 3,67 & 3,8 & 31,2 & 4,12 & 3,86 & 4,0 & 25,8 \\
\hline & & Rata-rata & & 4,7 & 29,9 & & & 5,3 & 24,1 \\
\hline
\end{tabular}

Tabel 4 Data IRI Hasil Roadbump Pro dengan Kendaraan Survei Jenis Sedan

\begin{tabular}{|c|c|c|c|c|c|c|c|c|c|}
\hline \multirow[b]{2}{*}{ STA } & \multirow[b]{2}{*}{ Interval } & \multicolumn{3}{|c|}{ IRI $(\mathrm{m} / \mathrm{km})$} & \multirow{2}{*}{$\begin{array}{c}\text { Kecepatan } \\
\text { Rata-rata } \\
(\mathrm{km} / \mathrm{jam})\end{array}$} & \multicolumn{3}{|c|}{ IRI (m/km) } & \multirow{2}{*}{$\begin{array}{r}\text { Kecepatan } \\
\text { Rata-rata } \\
(\mathrm{km} / \mathrm{jam})\end{array}$} \\
\hline & & $\begin{array}{c}\text { Rata-rata } \\
\text { Lajur } 1\end{array}$ & $\begin{array}{c}\text { Rata-rata } \\
\text { Lajur } 2\end{array}$ & $\begin{array}{c}\text { Rata- } \\
\text { rata }\end{array}$ & & $\begin{array}{c}\text { Rata-rata } \\
\text { Lajur } 3\end{array}$ & $\begin{array}{l}\text { Rata-rata } \\
\text { Lajur } 4\end{array}$ & $\begin{array}{c}\text { Rata- } \\
\text { rata }\end{array}$ & \\
\hline $000+100$ & 100 & 5,26 & 5,62 & 5,4 & 23,9 & 6,50 & 6,92 & 6,7 & 22,5 \\
\hline $000+200$ & 100 & 6,11 & 5,64 & 5,9 & 26,6 & 5,78 & 6,66 & 6,2 & 24,9 \\
\hline $000+300$ & 100 & 5,07 & 4,60 & 4,8 & 28,1 & 4,33 & 4,37 & 4,3 & 26,8 \\
\hline $000+400$ & 100 & 4,56 & 4,28 & 4,4 & 29,2 & 3,86 & 4,54 & 4,2 & 28,4 \\
\hline $000+500$ & 100 & 4,63 & 4,48 & 4,6 & 30,4 & 6,39 & 6,69 & 6,5 & 29,8 \\
\hline \multirow[t]{2}{*}{$000+600$} & 100 & 3,55 & 4,34 & 3,9 & 32,0 & 4,13 & 4,26 & 4,2 & 30,9 \\
\hline & & Rata-rata & & 4,8 & 28,4 & & & 5,4 & 27,2 \\
\hline
\end{tabular}

Tabel 5 Data IRI Hasil Roadbump Pro dengan Kendaraan Survei Jenis Pickup

\begin{tabular}{|c|c|c|c|c|c|c|c|c|c|}
\hline \multirow[b]{2}{*}{ STA } & \multirow[b]{2}{*}{ Interval } & \multicolumn{3}{|c|}{ IRI $(\mathrm{m} / \mathrm{km})$} & \multirow{2}{*}{$\begin{array}{c}\text { Kecepatan } \\
\text { Rata-rata } \\
(\mathrm{km} / \mathrm{jam})\end{array}$} & \multicolumn{3}{|c|}{ IRI $(\mathrm{m} / \mathrm{km})$} & \multirow{2}{*}{$\begin{array}{r}\text { Kecepatan } \\
\text { Rata-rata } \\
\text { (km/jam) }\end{array}$} \\
\hline & & $\begin{array}{l}\text { Rata-rata } \\
\text { Lajur } 1\end{array}$ & $\begin{array}{c}\text { Rata-rata } \\
\text { Lajur } 2\end{array}$ & $\begin{array}{c}\text { Rata- } \\
\text { rata }\end{array}$ & & $\begin{array}{c}\text { Rata-rata } \\
\text { Lajur } 3\end{array}$ & $\begin{array}{c}\text { Rata-rata } \\
\text { Lajur } 4\end{array}$ & $\begin{array}{c}\text { Rata- } \\
\text { rata }\end{array}$ & \\
\hline $000+100$ & 100 & 5,60 & 6,07 & 5,8 & 33,5 & 6,40 & 7,38 & 6,9 & 24,8 \\
\hline $000+200$ & 100 & 6,26 & 6,54 & 6,4 & 33,7 & 5,47 & 6,36 & 5,9 & 26,1 \\
\hline $000+300$ & 100 & 5,10 & 5,28 & 5,2 & 34,0 & 4,95 & 5,18 & 5,1 & 27,6 \\
\hline $000+400$ & 100 & 4,30 & 4,59 & 4,4 & 34,4 & 5,02 & 5,19 & 5,1 & 28,4 \\
\hline $000+500$ & 100 & 4,86 & 4,56 & 4,7 & 35,0 & 5,38 & 7,25 & 6,3 & 29,5 \\
\hline \multirow[t]{2}{*}{$000+600$} & 100 & 4,15 & 3,44 & 3,8 & 35,8 & 3,96 & 4,64 & 4,3 & 30,4 \\
\hline & & Rata-rata & & 5,1 & 34,4 & & & 5,6 & 27,8 \\
\hline
\end{tabular}

\section{Hubungan antara Data IRI dengan Jenis Kendaraan Survei}

Pengambilan data IRI dipengaruhi oleh jenis kendaraan. Penelitian ini menggunakan 3 jenis kendaraan yang berbeda, yakni MPV berupa mobil Avanza, sedan berupa mobil Toyota Corolla, dan pickup berupa mobil Mitsubishi Strada. Berdasarkan data pada Tabel 3 sampai dengan Tabel 5, dapat dibuat suatu korelasi antara IRI pengukuran Roadbump dan IRI pengukuran Roughometer III, seperti yang dapat dilihat pada Gambar 4.

Gambar 4 juga menunjukkan hubungan antara pembacaan IRI dengan jenis kendaraan tertentu terhadap IRI Roughometer sebagai validator. Koefisien determinasi $\left(\mathrm{R}^{2}\right)$ yang sangat baik ditunjukkan oleh kendaraan survei MPV, sedangkan jenis-jenis kendaraan lain, yaitu sedan dan pickup, memiliki koefisien determinasi yang cukup. Keunggulan MPV diduga berkaitan dengan umur kendaraan, yaitu sekitar 5 tahun, sehingga suspensi kendaraan masih cukup elastis. 


\section{Korelasi antara Data IRI Hasil Roadbump Pro dan Roughometer III}

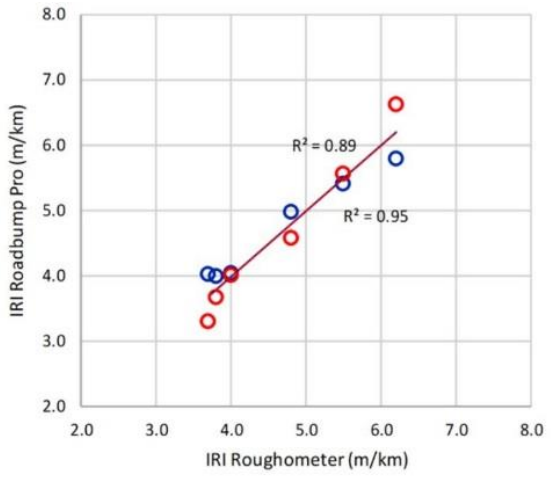

○ MPV_Lajur 1 0 MPV_lajur 2

— Linear (MPV_Lajur 1) -...-...- Linear (MPV_lajur 2)

(a)

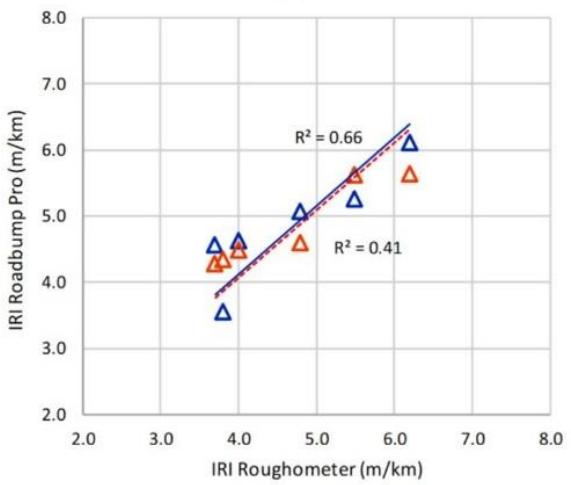

\section{$\Delta$ Sedan_Lajur 1 $\Delta$ Sedan_lajur 2}

Linear (Sedan_Lajur 1)

(c)
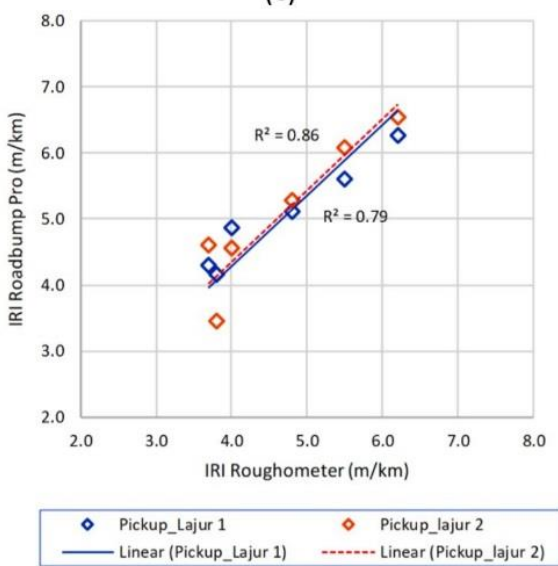

(e)

(a) Lajur 1 dan 2 dengan mobil MPV

(b) Lajur 3 dan 4 dengan mobil MPV

(c) Lajur 1 dan 2 dengan mobil sedan

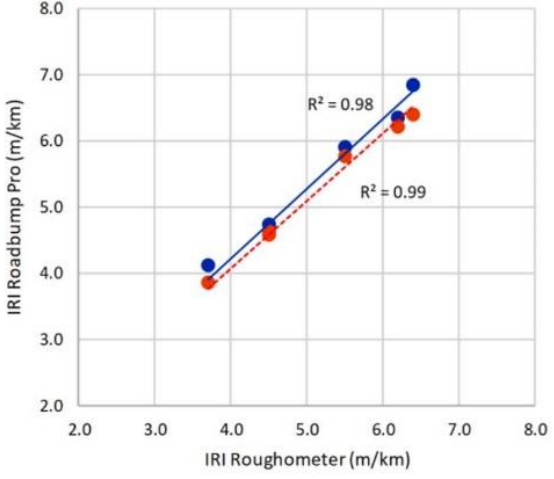

- MPV_Lajur 3 MPV_lajur 4

Linear (MPV_Lajur 3) -..-.-.-. Linear (MPV_lajur 4)

(b)

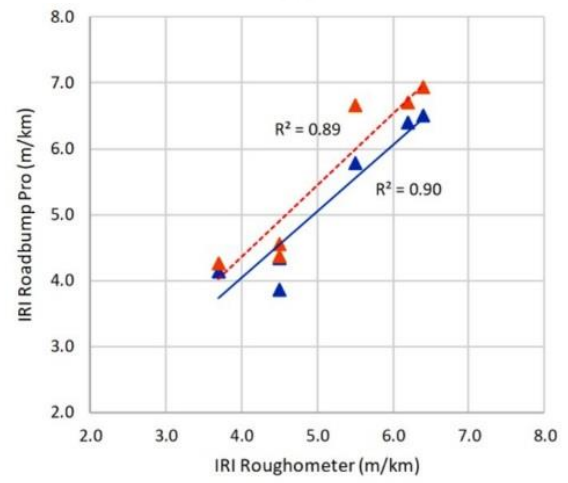

\ Sedan_Lajur 3 3 Sedan_lajur 4 Linear (Sedan_Lajur 3) - ------- Linear (Sedan_lajur 4)

(d)
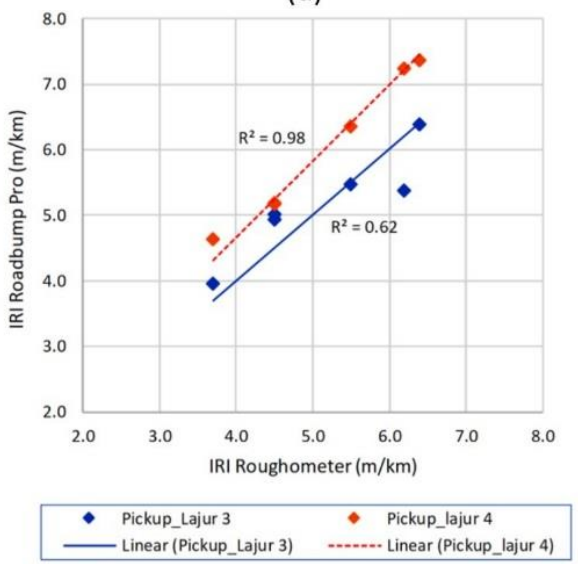

(f)

(d) Lajur 3 dan 4 dengan mobil sedan (f) Lajur 1 dan 2 dengan mobil pickup

(g) Lajur 1 dan 2 dengan mobil pickup

Gambar 4 Korelasi antara IRI Hasil Pengukuran Roadbump Pro dan Roughometer III

Korelasi antara IRI Roadbump Pro dan IRI Roughometer sebagai validatornya dapat diperoleh dengan melihat koefisien korelasi (akar kuadrat nilai koefisien determinasi) pada 
Gambar 4. Hasil yang diperoleh menunjukkan bahwa korelasi antara Roadbump Pro dengan validatornya memiliki hubungan yang sangat kuat.

Penggunaan mobil Avanza (MPV), sebagai kendaraan survei, memiliki koefisien korelasi lebih besar dari 0,94. Kendaraan sedan memiliki koefisien korelasi minimal 0,64 dan kendaraan jenis pickup memiliki koefisien korelasi minimal 0,79. Hal ini menunjukkan bahwa ketiga jenis kendaraan tersebut dapat digunakan sebagai kendaraan survei.

Korelasi ini menunjukkan bahwa penggunaan dan pemanfaatan aplikasi smartphone Roadbump Pro dalam penentuan IRI dapat dilakukan. Catatan yang perlu diperhatikan adalah jenis dan pemilihan usia kendaraan survei. Jenis kendaraan dapat disesuaikan dengan pemilihan faktor kendaraan atau vehicle/device factor dalam menu setting aplikasi.

\section{Hubungan antara Data IRI dan Pemilihan Lajur Survei}

Uji t berpasangan (paired t-test) diaplikasikan untuk mengetahui apakah antarlajur memiliki perbedaan IRI yang signifikan. Jika signifikan, masing-masing lajur tidak dapat dihilangkan dan keduanya (pasangan) harus disurvei. Data pada Tabel 3 sampai dengan Tabel 5 menunjukkan bahwa IRI Lajur 1 dan IRI Lajur 2 menunjukkan nilai p sebesar 0,710, 0,867, dan 0,856, yang berarti tidak signifikan, untuk MPV, sedan, dan pickup, berturutturut. Dengan demikian Lajur 1 dan Lajur 2 dapat diwakili oleh salah satu lajur saja untuk survei IRI.

Analisis statistika pada IRI Lajur 3 dan IRI Lajur 4 menghasilkan nilai p sebesar 0,031, 0,027, dan 0,025, yang berarti signifikan bila digunakan tingkat keandalan sebesar 0,05, untuk MPV, sedan dan pickup, berturut-turut. Hal ini menunjukkan bahwa IRI pada Lajur 3 dan pada Lajur 4 perlu diukur masing-masing. Secara umum, karena Lajur 3 dan Lajur 4 memberikan hasil perbedaan IRI yang signifikan, dianjurkan untuk dilakukan survei IRI pada masing-masing lajur, untuk menghindari kesalahan dalam memberikan kesimpulan mengenai kemantapan jalan berdasarkan data IRI.

Perbedaan pasangan antarlajur, signifikan atau tidak signifikan, berkaitan dengan faktor komposisi kendaraan dan distribusi arah pada lajur-lajur tersebut. Untuk Lajur 1 dan Lajur 2, umumnya pengendara melakukan perjalanan di sekitar kawasan tersebut, sedangkan untuk Lajur 3 dan Lajur 4 berasal dari luar Kota Palu. Berdasarkan data kendaraan yang melewati segmen Jalan Sam Ratulangi, jumlah kendaraan pada Lajur 3 dan Lajur 4 lebih besar dibandingkan yang terdapat pada Lajur 1 dan Lajur 2. Hal ini menunjukkan bahwa kedua faktor tersebut penting dalam kemantapan perkerasan jalan.

\section{Tingkat Kemantapan Jalan Sam Ratulangi Kota Palu}

Kemantapan Jalan Sam Ratulangi Kota Palu pada studi ini dinilai pada segmen sepanjang 600 meter dan dianalisis per 100 meter. Hasil kemantapan jalan per 100 m per lajur dipresentasikan pada Gambar 5. Hasil perhitungan menunjukkan bahwa kemantapan Jalan Sam Ratulangi, berdasarkan Roughometer nilai IRI antara 4,4 m/km hingga 5,1 m/km dan berdasarkan Roadbump nilai IRI antara 4,7 m/km hingga 5,6 m/km, menunjukkan kondisi yang sama, yaitu memenuhi tingkat jalan mantap. Namun, jika dicermati lebih detail 
per 100 meter, terdapat beberapa spot (diberi tanda broken line berbentuk lingkaran) yang masuk dalam kondisi tidak mantap.

Gambar 5 (a) sampai dengan Gambar 5 (f) menunjukkan konsistensi bagian jalan yang masuk dalam kategori tidak mantap. Dapat dikatakan bahwa Roadbump dan Roughometer konsisten dalam mengukur kekasaran permukaan jalan. Gambar 5 untuk Lajur 1 dan Lajur 2 menunjukkan kemantapan jalan yang lebih baik jika dibandingkan dengan Lajur 3 dan Lajur 4. Hal ini sejalan dengan kenyataan bahwa masing-masing lajur dan arah memiliki karakteristik arus lalu lintas yang berbeda, sehingga memengaruhi kemantapan jalan selama masa layan.

Penggunaan nilai rata-rata dalam penentuan kemantapan suatu jalan perlu diperhatikan pada spot tertentu yang dalam kondisi berbeda, yang dalam hal ini jalan tidak mantap, tetapi secara rata-rata segmen jalan dinilai mantap. Oleh karena itu, perlu suatu kriteria tingkat keseragaman secara statistika dengan tingkat kepercayaan tertentu, sehingga dapat diketahui rentang IRI yang diizinkan akibat spot yang memiliki perbedaan tersebut.
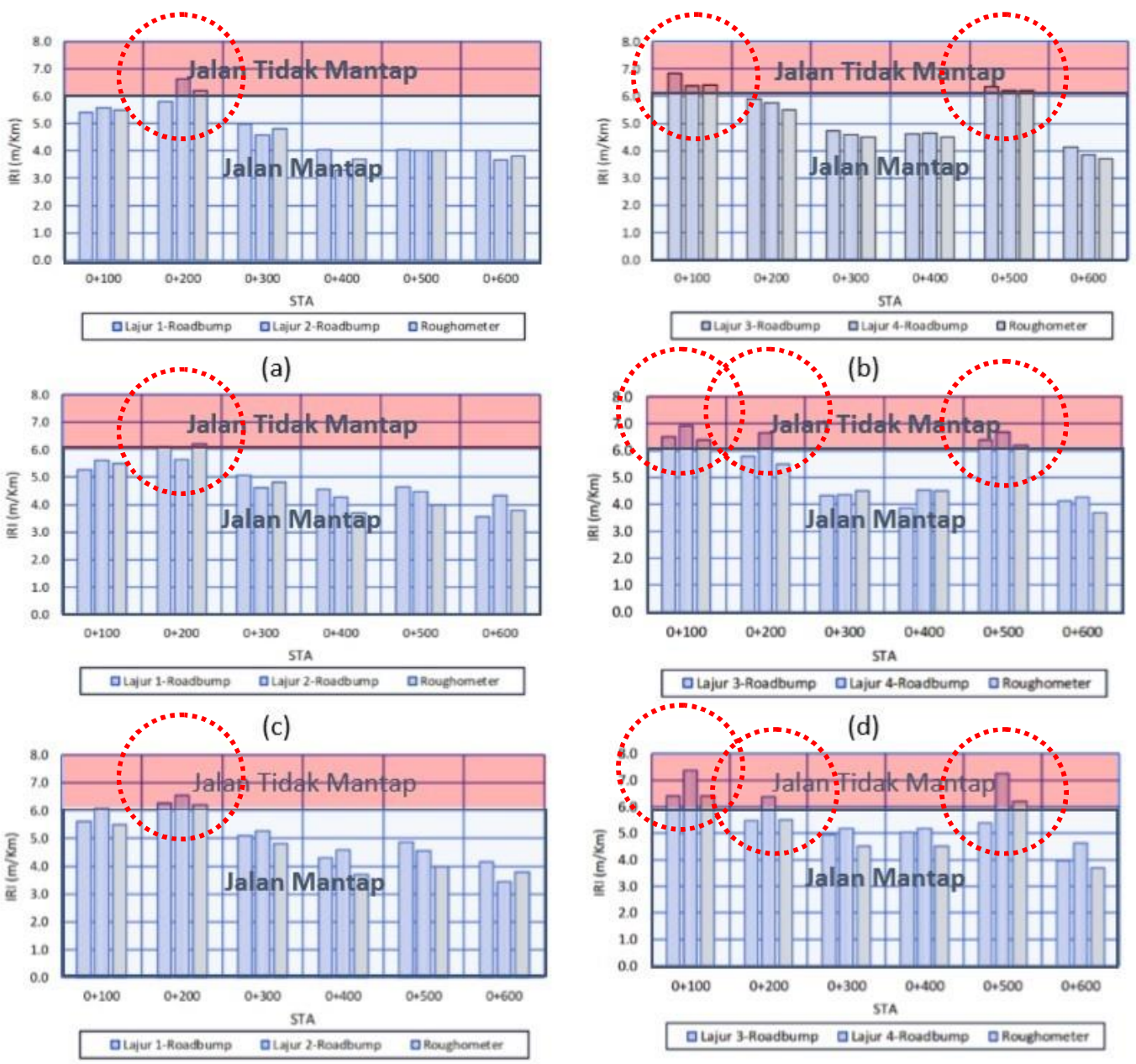

(e)

(f)

(a) Lajur 1 dan 2 dengan mobil MPV

(b) Lajur 3 dan 4 dengan mobil MPV

(c) Lajur 1 dan 2 dengan mobil Sedan

(d) Lajur 3 dan 4 dengan mobil Sedan

(f) Lajur 1 dan 2 dengan mobil pickup

(g) Lajur 1 dan 2 dengan mobil pickup

Gambar 5 Tingkat Kemantapan Jalan Sam Ratulangi Per 100 m 


\section{KESIMPULAN}

Berdasarkan studi ini dapat ditarik kesimpulan sebagai berikut:

1) Aplikasi android Roadbump Pro memberikan hasil pengukuran IRI yang memuaskan, dengan ditunjukkan oleh nilai korelasi secara keseluruhan lebih besar dari 0,6, sehingga dapat digunakan sebagai pilihan tool dalam penilaian kemantapan jalan; dan

2) Faktor jenis kendaraan tidak memiliki pengaruh yang signifikan terhadap pengukuran IRI. Hal yang perlu diperhatikan adalah setting vehicle/device factor dan pemilihan umur atau kondisi kendaraan survei.

\section{DAFTAR PUSTAKA}

Australian Road Research Board. 2016. Roughometer III. Port Melbourne, VIC.

Badan Standardisasi Nasional. 1994. Tata Cara Survei Kerataan Permukaan Perkerasan Jalan dengan Alat Ukur Kerataan NAASRA. SNI 03-3426-1994. Jakarta.

Badan Standardisasi Nasional. 2004. Geometri Jalan Perkotaan, Standar Nasional Indonesia, RSNI T-14-2004. Jakarta.

Balai Pelaksanaan Jalan Nasional XIV. 2018. Data IRI Ruas Jalan Sam Ratulangi Berdasarkan Roughometer III (tidak dipublikasikan). Palu.

Gillespie, T.D., Sayers, M.W., dan Segel, L. 1980. Calibration of Response-Type Road Roughness Measuring Systems. NCHRP Report 228. Transportation Research Board, National Research Council. Washington, DC.

Grimmer Software. 2019. Measure the Roughness of A Road with Your Phone's GPS and Accelerometer Sensors. (Online), (http://www.grimmersoftware.com/roadbump.html, diakses 14 Juli 2019, 7:04 PM).

Kementerian Pekerjaan Umum. 2011. Peraturan Menteri Pekerjaan Umum No. 13/PRT/M/ 2011 tentang Tata Cara Pemeliharaan dan Penilikan Jalan. Jakarta.

Paterson W.D.O. 1986. International Roughness Index: Relationship to Other Measures of Roughness and Riding Quality. Transportation Research Record 1084: Pavement Roughness and Skid Resistance, United States of America.

Pembuain, A., Priyanto, S., dan Suparma, L. 2018. Evaluasi Kemantapan Permukaan Jalan Berdasarkan International Roughness Index pada 14 Ruas Jalan di Kota Yogyakarta. Jurnal Teknik, 39 (2): 126-13.

Tho'atin, U., Setyawan, A., dan Suprapto, M. 2016. Penggunaan Metode International Roughness Index (IRI), Surface Distress Index (SDI) dan Pavement Condition Index (PCI) untuk Penilaian Kondisi Jalan di Kabupaten Wonogiri. Prosiding Seminar Nasional Sains dan Teknologi, Universitas Muhammadiyah, Jakarta. 